\title{
The Reference of Beijing Opera to the Teaching of Vocal Music in Colleges and Universities__ On the Reform and Innovation of Vocal Music Teaching
}

\author{
Fan Qiuyue
}

Heihe College, Heilongjiang, China

Keywords: vocal music art; technology; individuality; vocal music teaching in colleges and universities

\begin{abstract}
The two most basic elements in vocal music singing are technology and individuality. The problem of the singing technology and individuality is a hot topic in recent years in Chinese vocal music circles. Through research, it is easy to see that singing skills and individuality are complementary to each other. Technology is an important condition for supporting individuality, and individuality is the eternal pursuit of vocal music. The national character is an important character of vocal music art. It is a sacred mission to raise the humanistic spirit and inherit the culture. In the teaching of vocal music, it should be local and grounded as much as possible, and continue to reform and innovate in the protection, inheritance and promotion of Chinese music culture.
\end{abstract}

\section{Introduction}

When internationalization and globalization have become the mainstream and trend of the development of the world, with the development of modern science and technology, the pace of the times is moving closer to the top of the world. The standardization and internationalization of technology is emphasized more and more, regardless of product manufacturing, sports or music art. No doubt, no doubt about the technology. The lax pursuit has promoted the development of social and economic culture. However, standardization and internationalization will inevitably lose some of the active personality, so it is said that technology has obliterated the personality. When some of the things are flattened and the differences no longer exist, its attractiveness will naturally fall.While we advocate the integration of vocal education with the world, we find that the vocal music works and singing, which are original and full of national characteristics, are getting far away from us.

\section{The Important Condition of Technology for Supporting Individuality}

The original ecology, a noun that appears to be new, was spread overnight in various media, but it was a misconception that had appeared in the 1960s, but at that time the "original ecology" had not been used in culture, but was first accepted and made by the biological community. Use. We seem to be able to explain this: This is a form of art that has not been "corroded" by modern scientific and technological means, relying only on the way of folk oral and oral instruction, which is almost primitive and has a strong local flavor.

Singing skills and personality are complementary to each other. The two most basic elements of vocal music singing are technology and personality, and the correct handling of the relationship between technology and personality can achieve the perfect unity of singing skills and personality expression. If there is no certain vocal technology, the moving emotion can not convey the wonderful music to the audience; on the other hand, if the music or singing itself lacks personality and emotion, the high skill can not be touched. The pursuit of singing technology and personality is like the three realm of Zen learning: the first realm, the mountain is the mountain, the water is water, the second realm, the mountain is not the mountain, the water is not water, the third state, the mountain or the mountain, the water or the water. When looking at mountains and mountains, and watching the water is the state of water, singers often concentrate on learning singing techniques. 


\section{Singing Techniques Serve Different Ethnic Cultures}

Due to various reasons such as history, vocal music teaching in Chinese universities has basically formed a teaching method based on western bel canto. Bel canto is a singing style with traditional European vocal music, especially Italy vocal music technology. It "with beautiful tone color, rich in change; the sound division is strict, pay attention to the harmonious unity of the sound area; sound method science, volume plasticity, sound air consistency, sound and sound connection smooth and clean." This style of singing has a great influence on the world. This is why the vocal music teaching in Colleges and universities in China is becoming western. We do not deny the advantages of vocal singing, but the argument that bel canto is the only scientific method of sound is biased. Art has no "right and wrong" points, singing technology is not "good and bad", it can not be used to make a simple judgment or not, in fact, different vocal art represents no one. The same life embodies different cultures and expresses different city beauty.

\section{Singing Techniques are Subordinated to Different Vocal Works and Emotional Expressions}

Singing skills are also changed because of different works. The corresponding singing techniques should be determined according to the style, category, content and emotion of vocal music itself. Even if they are Chinese folk songs, such as Jiangnan folk songs, Mongolia long tune, team North Xin Tian tour, northwest flower and so on, the singing methods are different. Some breath is shallow, the voice is thin and ingenious; some breath is deep, the voice is loud and stirring; some breath is deep or shallow, the voice is sometimes exquisite and lingering, sometimes bright brilliant. Soprano professor Zhou Xiaoyan once said that all the singing skills are for vocal music works. What style and content do you sing, you can use the appropriate skills, voice and emotion to express it. The famous singer, Professor Shen Xiang, also mentioned the singing methods in different times. The singing forms, styles, emotions and emotions are different in different times, and the methods of singing are also different.Besides, beautiful voice is the basis for expressing feelings, and technology is also for emotional service. In "Yue Ji", it is mentioned that "from the beginning of the sound, the movement of the heart, the object is also felt, and it is formed in the sound." This shows that singing is caused by emotion, and that is where love comes from. Singing at all times and in all parts of the world is not the sound of love, but the singing of words by emotion. The music thought of Chinese Taoism belongs to nature and nature, and advocates the free spirit of innocence and nature. It emphasizes that singing is the natural expression and expression of emotion, and does not need to be affected. On the basis of understanding the content of the works and the artistic conception of the melody, the connotation of the music can be reached through certain singing techniques.

\subsection{Vocal music teaching in colleges and universities should be local and grounded.}

Music is a spiritual culture with its own charisma. As an institution of higher learning to foster humanistic spirit, inheriting culture is one of its important tasks. Colleges and universities are also the most concentrated places for music talents. They are the best research and protection of folk music.

The base of culture. However, because of many historical reasons, the teaching of vocal music in Colleges and universities has always followed the vocal music teaching system dominated by the professional music college, which is dominated by the sound of sound, and ignores the traditional Chinese vocal music culture. Then how to reflect the national characteristics and carry forward the Chinese music culture in college vocal music teaching? We believe that for vocal music teaching, it is necessary to inherit the most original national art, to highlight the national character, and to combine the popular singing forms with the classroom teaching in the folk. The teaching of vocal music in Colleges and universities should be as much as possible and ground to the ground. The following author will discuss teaching contents from three aspects: teaching objectives, teaching contents and teaching methods. 


\subsection{Teaching goal.}

Colleges and universities are the main positions of vocal music teaching and scientific research, and have unique advantages in carrying forward traditional Chinese music culture. In order to change the vocal music teaching system dominated by vocal singing, and to protect and inherit Chinese music culture, it is necessary to establish the important position of Chinese national music in the teaching of vocal music in Colleges and universities, and form our own musical culture education system. Under the guidance of this teaching goal, colleges and universities should increase the proportion of traditional national vocal music in vocal music teaching, reorganize the professional courses, adjust the structure of teachers reasonably, make necessary supplements to the teaching facilities, and reform the school style and teaching research management at the same time so that this can be realized. The theoretical reconstruction and value return of the soil music culture make Chinese music culture occupy a place in the international arena.

\subsection{Content of courses.}

The national vocal music itself manifests the national character, and is the carrier and embodiment of the national music style. In the teaching of vocal music, a lot of singing of Chinese vocal music is introduced to let students feel the beauty of Chinese traditional music from the beginning, which is also an important embodiment of the national character of vocal music teaching in Colleges and universities. Therefore, colleges and universities should carry out a series of reform and innovation in teaching content. First of all, in order to make students sing more vocalities and connotations of national vocal music works, we must pay attention to cultivating students' national feelings and cultural identity. Therefore, in the teaching of vocal music, universities should add national characteristics of national studies, literature, philosophy, aesthetics and other courses to enable students to comprehend the essence of Chinese traditional culture, cultivate national emotion and national temperament, so that they can make the music features of the Chinese nation like flowing out naturally in the singing.

\section{Conclusion}

According to the general law of the development of things, it is not essentially different from the technology of other industries, and with the development of the society and the progress of technology, it is a permanent development, often a new field of learning, and it is endless. And personality is the characteristics and characteristics of the development of things to a certain stage. The personality of music is produced in different cultural backgrounds. The traditional Chinese music of the Chinese nation is rooted in the foundation of Chinese traditional culture. Individuality is fresh, full of vitality and appeal, and needs me.They feel and understand. Only by integrating the singing skills and personality organically can we achieve the unity of voice and emotion. In order to make Chinese music culture emit a unique national charm in the forest of the world's national art, as an institution of higher education for cultivating music talents and inheriting music culture, it must be based on our native music culture, excavate the Chinese traditional music culture systematically, and carry out a series of reform and innovation in the teaching of vocal music. . Rooted in tradition, we draw the essence from the traditional vocal music art, so that we can find it in vocal art.

The "root" of the Chinese nation feels the soul of the Chinese nation. Of course, the emphasis on the inheritance and development of local music culture does not mean to reject multicultural achievements, but to absorb and integrate the fresh elements of contemporary music development on the basis of local music culture, and finally make the national vocal music art developing and perfecting.

\section{Acknowledgement}

Topic:The practice of singing and playing in Beijing Opera,Subject category: The project of the 
Provincial Education Department,Topic number: JJc1317109

\section{References}

[1] Wei Lili. Some thoughts on the current folk singing method [J]. people's music, 2011 (5).

[2] Wei Changyong. Personality and skills discussed in the fifteen green song competition.

[3] Meng Xinyang, Colleen. Theoretical course of national vocal music [M]. Beijing: Minzu University of China press, 2009.

[4] Zhang Xian Sheng. The development and change of Chinese traditional vocal music technology from the perspective of aesthetic interest transfer [J]. Chinese musicology, 2003 (4).

[5] Chen Jianbin. Three kinds of singing method "non singing method" -- Reflections on related phenomena in vocal music teaching in Colleges and universities, [J]. art exploration, 2011 (4).

[6] Guo Qiang. Talking about vocal singing skills and showing the artistic charm of songs. [J]. music exploration, 2010 (3).

[7] Shang Yuan. The aesthetic experience of vocal singing skills and emotional expression [J]. mass technology, 2010 (6).

[8] Liu Chenghua. Humanistic interpretation of Chinese music [M]. Shanghai: Shanghai music publishing house, 2002. 